\title{
CLADOCERA FAUNA COMPOSITION IN A RIVER-LAGOON SYSTEM OF THE UPPER PARANÁ RIVER FLOODPLAIN, WITH A NEW RECORD FOR BRAZIL
}

\author{
SERAFIM Jr., M., ${ }^{1,2}$ LANSAC-TÔHA, F. A., ${ }^{2}$ PAGGI, J. C., ${ }^{3}$ VELHO, L. F. M. ${ }^{2}$ \\ and ROBERTSON, B. ${ }^{2}$ \\ 'Pontifícia Universidade Católica do Paraná, Departamento de Biologia, Rua Imaculada Conceição, 1155, \\ CEP 80215-901, Curitiba, PR, Brazil \\ ${ }^{2}$ Universidade Estadual de Maringá, NUPELIA, Curso de Pós-graduação em Ecologia de \\ Ambientes Continentais, Av. Colombo, 5790, CEP 87020-900, Maringá, PR, Brazil \\ ${ }^{3}$ Instituto Nacional de Limnologia, INALI, Jose Macia, 1933, 3016, Santo Tomé, Argentina \\ Correspondence to: Moacyr Serafim Jr., Pontifícia Universidade Católica do Paraná, Departamento de Biologia, \\ Rua Imaculada Conceição, 1155, CEP 80215-901, Curitiba, PR, Brazil, e-mail: mserafim@ rla01.pucpr.br \\ Received February 25, 2002 - Accepted Juny 10, 2002 - Distributed May 31, 2003
}

(With 3 figures)

\begin{abstract}
Cladocera communities were studied in lotic and lentic environments of the Upper Paraná River floodplain, State of Mato Grosso do Sul, Brazil. A total of 63 species of Cladocera were identified in 108 samples. Of these, 24 species are considered new records for that floodplain, and one is a new record for Brazil. Chydoridae was the most representative family with 19 genera and 39 species.
\end{abstract}

Key words: Cladocera, species richness, floodplain, Upper Paraná River.

\section{RESUMO}

\section{Composição de cladóceros em um sistema rio-lagoa na planície de inundação do alto rio Paraná, Brasil}

A comunidade de cladóceros foi estudada em ambientes lótico e lêntico na planície de inundação do alto rio Paraná, Estado do Mato Grosso do Sul, Brasil. Foram identificadas 63 espécies em 108 amostras. Deste total, 24 espécies são consideradas novos registros para essa planície de inundação e uma espécie é um novo registro para o Brasil. Chydoridae foi a família mais representativa, com 19 gêneros e 39 espécies.

Palavras-chave: Cladocera, riqueza de espécies, planície de inundação, rio Paraná.

\section{INTRODUCTION}

River floodplains are non-equilibrium systems whose ecological integrity depends upon a certain level of disturbance (Ward et al., 1999). These environments, strongly influenced by water level fluctuations, are heterogeneous landscapes with high biological diversity. The Upper Paraná River floodplain is one of the few remaining non-dammed stretches of the Paraná River in Brazil. Multidisciplinary studies have shown that this remnant floodplain retains high biodiversity and that it is fundamental in maintaining those species already eliminated from the other areas of the Paraná River basin (Agostinho \& Zalewski, 1996; Paggi, in press).

Numerical data on the Cladocera fauna of Neotropical river floodplain systems are still too few and most studies have considered primarily pelagic species. Lack of data on the littoral fauna of these environments can basically be attributed to sampling difficulties and taxonomical problems. Good estimates of the number of species occurring in neotropical regions can be found in Paggi \& José de Paggi (1990) and Paggi (1995). The preliminary 
biogeographical synthesis of the Neotropical Cladoceran fauna given by Paggi (1993, 1995) points out the basic features of this fauna:

(i) it is poor in endemics at high taxonomic levels, contrasting with Holarctic and Australasian regions;

(ii) only the families Macrothricidae and Chydoridae have endemic genera;

(iii) there is no endemism in neotropical regions shared with the Ethiopian region, with the exception of Moina reticulate;

(iv) Sididae, Macrothricidae, and Chydoridae are more diverse in tropical and subtropical waters.

It is important to note that the Paraná River basin harbours a very rich zooplanktonic fauna, in many cases associated to littoral habitats (Paggi, 1972, 1975, 1979, 1980, 1983, 1987, 1990, 1995, in press; Corrales de Jacobo \& Frutos, 1985; MatsumuraTundisi, 1986; Paggi \& José de Paggi, 1990; Lima et al., 1996; Lansac-Tôha et al., 1997; Sendacz, 1997). The loss of environmental heterogeneity and habitats, a consequence of construction in the Paraná River basin, can be considered a major threat to this fauna (Paggi, in press). This paper presents data on the composition of the cladoceran fauna collected in the Ivinhema River and Patos Lagoon, located in the Upper Paraná River floodplain, State of Mato Grosso do Sul, and includes new records for the study area and a new record for Brazil.

\section{MATERIAL AND METHODS}

The Ivinhema River ( $22^{\circ} 49^{\prime} \mathrm{S}, 53^{\circ} 34^{\prime} \mathrm{W}$ ) is the main meandering tributary of the upper Paraná River right bank. The average declivity is $10.8 \mathrm{~cm} \cdot \mathrm{km}^{-1}$ and the average current speed in the river channel is 0.85 $\mathrm{m} . \mathrm{s}^{-1}$. Patos Lagoon (22 $\left.49^{\prime} \mathrm{S}, 5^{\circ} 33^{\prime} \mathrm{W}\right)$ is a small marginal lagoon $\left(\sim 1.2 \mathrm{~km}^{2}\right)$ with depths ranging between 2.8 and $4.8 \mathrm{~m}$. It is connected year-round with the Ivinhema River by a permanent channel and is therefore directly influenced by the oscillation of the river water level (Fig. 1).

The marginal vegetation of both river and lagoon is composed of trees, shrubs, grass (Panicum sp.), and dense stands of aquatic macrophytes of the genera Eichhornia, Salvinia, and Polygonum, among others. Samples were collected at nine sites. The type of environment, whether lentic or lotic, and the predominant marginal vegetation are described in Table 1.

The sampling sites were visited at monthly intervals from March 1993 to February 1994. A total of 108 samples were collected. High temperatures, neutral $\mathrm{pH}$, and low electrical conductivity are common to both environments (Thomaz et al., 1997). Low oxygen concentrations occur during the high water periods and high oxygen concentrations occur during the low water ones (Thomaz et al., 1997).

Cladocerans were collected by filtering $1 \mathrm{~m}^{3}$ of surface water through a $68 \mu \mathrm{m}$ mesh conical net, with the aid of a motorized pump.

TABLE 1

Description of sampling sites.

\begin{tabular}{|c|l|c|c|}
\hline & \multicolumn{1}{|c|}{ Collecting site } & Environment & Vegetation \\
\hline 1 & Pelagic region of connecting channel & Lentic & - \\
\hline 2 & Littoral region of lagoon & Lentic & Eichhornia azurea \\
\hline 3 & Pelagic region of lagoon & Lentic & - \\
\hline 4 & Littoral region of lagoon & Lentic & Panicum sp. \\
\hline 5 & Littoral region of lagoon & Lentic & Polygonum sp./E. azurea \\
\hline 6 & Littoral region of lagoon & Lentic & Polygonum sp./E. azurea \\
\hline 7 & Left margin of river & Lotic & E. azurea/Polygonum sp./E. crassipes \\
\hline 8 & Pelagic region of river & Lotic & - \\
\hline 9 & Right margin of river & Lotic & Trees/shrub \\
\hline
\end{tabular}




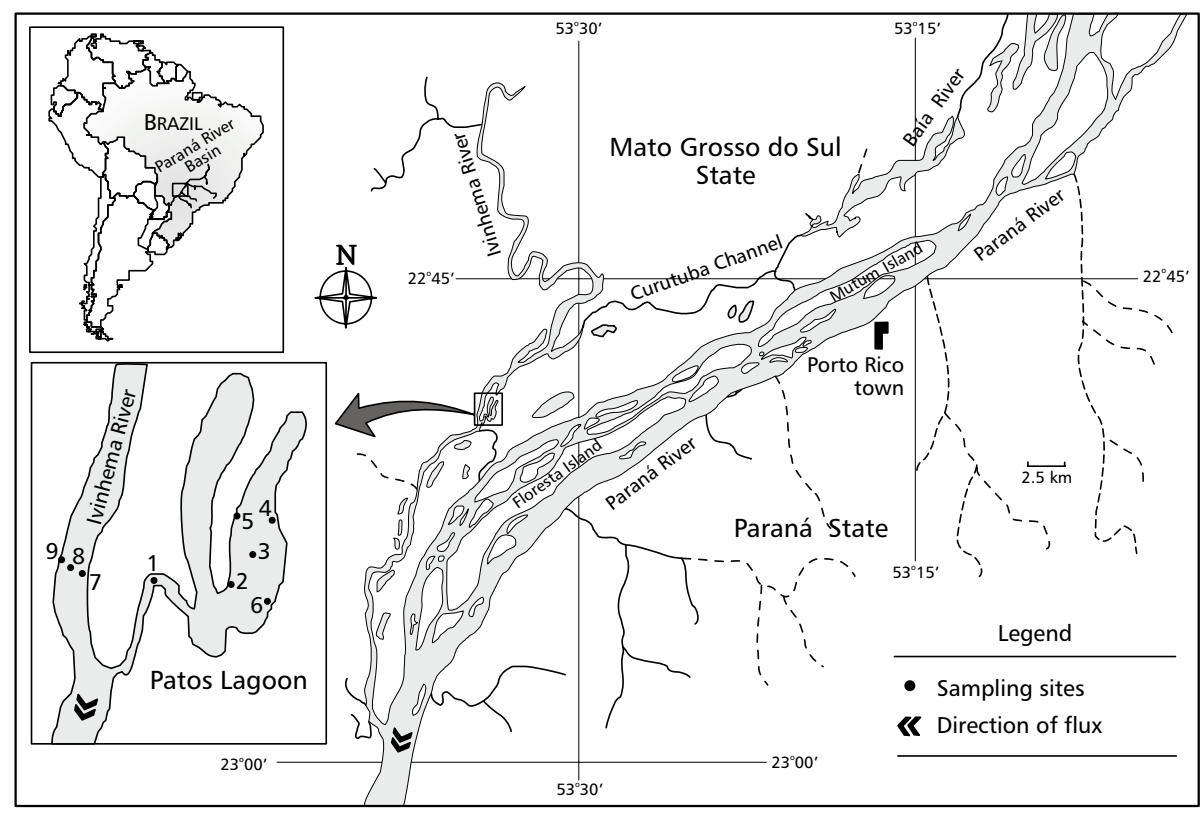

Fig. 1 - Study area and sampling sites in the Upper Paraná River floodplain, Brazil.

The samples were preserved in $4 \%$ buffered formalin. Identification of the species was based on Paggi (1972, 1975, 1979, 1980, 1983, 1987, 1995); Korinek (1981); Smirnov (1992, 1996); Korovchinsky (1992); and Elmoor-Loureiro (1997).

A constancy index (c) for each species per site was calculated according to Dajoz (1973). According to this index, constant species are those present in more than $50 \%$ of the samples; accessory species are those present in $25 \%$ to $50 \%$ of the samples, and accidental species are those present in up to $25 \%$ of the samples.

The occurrence and frequency of each species were obtained as follows: $\mathrm{S}=\mathrm{n} / \mathrm{N} .100$, where $\mathrm{n}$ is the number of samples in which the species occurred and $\mathrm{N}$ is the total number of samples.

\section{RESULTS}

A total of 63 species of Cladocera were identified. Of these, twenty-four are new records for the Upper Paraná River floodplain, and one is a new record for Brazil. Chydoridae was the most representative family with 19 genera and 39 species. Sididae followed with 3 genera and 7 species and Macrothricidae with 4 genera and 5 species (Fig. 2).

The following are new records for the Upper Paraná River floodplain: Bosmina longirostris, Diaphanosoma polyspina, Latonopsis brevireme, Moina reticulata, Moinodaphnia macleayii, Guernella raphaelis, Alona cf. anodonta, A. cf. cambouei, A. fasciculata, A. cf. intermedia, A. verrucosa, Alonella excisa, Chydorus strictomarginatus, Chydorus parvireticulatus, C. nitidulus, Dadaya macrops, Ephemeroporus acanthodes, E. barroisi, E. hybridus, E. tridentatus, Eurycercus lamellatus, Kurzia longirosris, Oxyurella longicauda, and Pseudochydorus globulosus. The occurrence of $C$. strictomarginatus is the first recorded for Brazil.

The most frequent species were: Bosminopsis deitersi (94\%), Ilyocryptus spinifer (85\%), Disparalona dadayi (84\%), Bosmina hagmanni (74\%), Alona cf. fasciculata (72\%), Chydorus pubescens (71\%), C. eurynotus (67\%), and Macrothrix spinosa (65\%). 


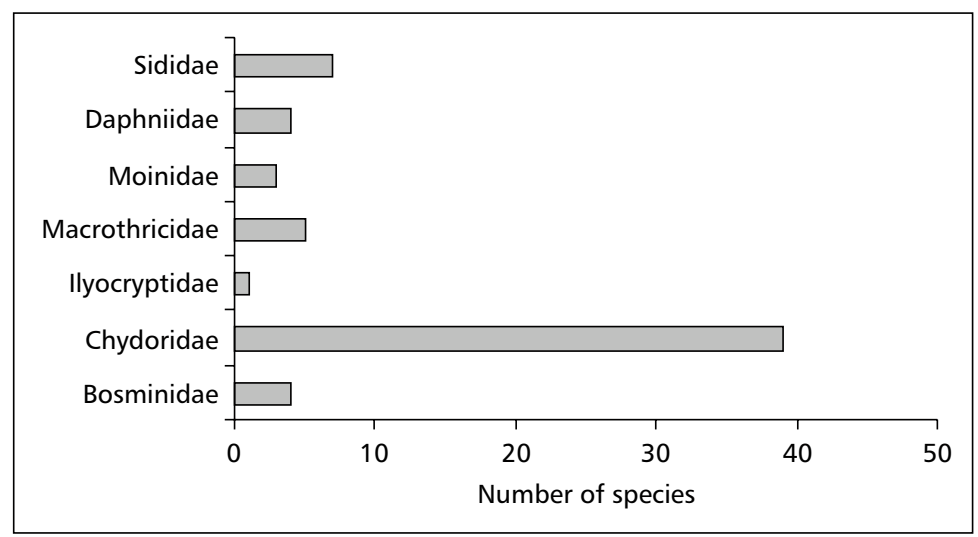

Fig. 2 - Number of cladoceran species per family found in the Upper Paraná River floodplain.

The greatest number of constant species was found in the littoral sampling sites of the lagoon (sites 2 and 5) and the river (site 7). The lowest number of constant species was found in the pelagic region of the canal and the lagoon (sites 1 and 3), and in the littoral region of the lagoon where Panicum was the dominant macrophyte (site 4). The Ivinhema River had a greater number of constant species than the lagoon did (Table 2) (Figure 3).

Bosminopsis deitersi, Ilyocryptus spinifer, and Disparalona daday were the only species constant at all sampling sites. B. hagmanni, A. cf. fasciculata, $C$. pubescens, C. eurynotus, and $M$. spinosa were constant at most sampling sites. However, $B$. hagmanni was classified as an accessory species in the littoral region of the lagoon, with large stands of E. azurea (site 2), and M. spinosa was classified as an accessory species in the pelagic region of both the canal and the lagoon (sites 1 e 3 ). Among the Chydoridae, A. cf. fasciculata was classified as an accessory species in the pelagic region of the lagoon (site 3); C. pubescens was classified as an accessory species in the pelagic region of the lagoon (site 3 ) and in the littoral region of the lagoon in the presence of Panicum sp. (site 4); and C. eurynotus was classified as an accessory species in the pelagic region of the lagoon (site 3 ) and in the littoral region of the lagoon near Poligonum sp. and E. azurea stands (site 6) (Table 2).
Alona monacantha was an accessory species at most sampling sites, but at site 2 near extensive stands of E. azurea it was constant. Thirty species were accidental in the entire study area. Of these, only $M$. reticulata was recorded at all sites. Diaphanosoma birgei, Simocephalus serrulatus, and Leydigiopsis curvirostris were registered at eight of the nine sampling sites. Daphnia gessneri, D. polyspina, D. spinulosum, Dadaya macrops, Eurycercus lamellatus, Ephemeroporus barroisi, and Pseudochydorus globulosus were not observed in the Ivinhema River sites (Table 2). The greatest number of accidental species, 37, was observed in the pelagic region of the channel (site 1) and the least, 21 , on the right bank of the river which did not have marginal vegetation (site 9).

\section{DISCUSSION}

According to Korovchinsky (1996), the estimate of the number of fresh water cladoceran species in the world is in the range of 600. Of these, only 129 species can be considered as valid species or as sufficiently well described, while about 146 species are relatively well described, and the status of all other species is vague. The number of Cladocera species recorded in this study (63) is higher than the total recorded previously (40) from different environments of the Upper Paraná River floodplain (Lima et al., 1996; Lansac-Tôha et al., 1997). 
TABLE 2

Faunistic inventory and constancy index at different sampling sites on the Upper Paraná River floodplain, Brazil.

\begin{tabular}{|c|c|c|c|c|c|c|c|c|c|}
\hline Species & 1 & 2 & 3 & 4 & 5 & 6 & 7 & 8 & 9 \\
\hline \multicolumn{10}{|l|}{ Sididae } \\
\hline \multicolumn{10}{|l|}{ Diaphanosoma birgei Korinek, 1981} \\
\hline \multicolumn{10}{|l|}{ Diaphanosoma brevireme Sars, 1901} \\
\hline \multicolumn{10}{|l|}{ Diaphanosoma fluviatile Hansen, 1899} \\
\hline \multicolumn{10}{|c|}{ Diaphanosoma polyspina Korovchinky, 1982} \\
\hline \multicolumn{10}{|c|}{ Diaphanosoma spinulosum Herbst, 1975} \\
\hline \multicolumn{10}{|l|}{ Latonopsis brevireme Daday, 1905} \\
\hline \multicolumn{10}{|l|}{ Sarsilatona serricauda (Sars, 1901) } \\
\hline \multicolumn{10}{|l|}{ Daphniidae } \\
\hline \multicolumn{10}{|l|}{ Ceriodaphnia cornuta Sars, 1886} \\
\hline \multicolumn{10}{|l|}{ Daphnia gessneri Herbst, 1967} \\
\hline \multicolumn{10}{|l|}{ Simocephalus serrulatus (Koch, 1841) } \\
\hline \multicolumn{10}{|l|}{ Simocephalus vetulus Schödler, 1852} \\
\hline \multicolumn{10}{|l|}{ Moinidae } \\
\hline \multicolumn{10}{|l|}{ Moina minuta Hansen, 1899} \\
\hline \multicolumn{10}{|l|}{ Moina reticulata (Daday, 1905) } \\
\hline \multicolumn{10}{|l|}{ Moinodaphnia macleayii (King, 1853) } \\
\hline \multicolumn{10}{|l|}{ Macrothricidae } \\
\hline \multicolumn{10}{|l|}{ Echinisca elegans Sars, 1901} \\
\hline \multicolumn{10}{|l|}{ Grimaldina brazzai Richard, 1892} \\
\hline \multicolumn{10}{|l|}{ Guernella raphaelis Richard, 1892} \\
\hline \multicolumn{10}{|l|}{ Macrothrix spinosa King, 1953} \\
\hline \multicolumn{10}{|l|}{ Macrothrix triserialis (Brady, 1886) } \\
\hline Ilyocryptidae & & & & & & & & & \\
\hline Ilyocryptus spinifer Herrick, 1884 & & & & & & & & & \\
\hline Chydoridae & & & & & & & & & \\
\hline Acroperus harpae Baird, 1843 & & & & & & & & & \\
\hline Alona affinis (Leydig, 1986) & & & & & & & & & \\
\hline Alona cf. anodonta Daday, 1905 & & & & & & & & & \\
\hline Alona cf. cambouei Guerne \& Richard & & & & & & & & & \\
\hline Alona dentifera (Sars, 1901) & & & & & & & & & \\
\hline Alona eximia Kiser, 1948 & & & & & & & & & \\
\hline Alona fasciculata Daday, 1905 & & & & & & & & & \\
\hline Alona glabra Sars, 1901 & & & & & & & & & \\
\hline Alona cf. intermedia Sars, 1862 & & & & & & & & & \\
\hline Alona karua King, 1853 & & & & & & & & & \\
\hline Alona monacantha Sars, 1901 & & & & & & & & & \\
\hline Alona verrucosa Sars, 1901 & & & & & & & & & \\
\hline Alona sp. & & & & & & & & & \\
\hline Alonella excisa (Fischer, 1854) & & & & & & & & & \\
\hline Camptocercus dadayi Stingelin, 1914 & & & & & & & & & \\
\hline
\end{tabular}


TABLE 2 (Continued.)

\begin{tabular}{|c|c|c|c|c|c|c|c|c|c|}
\hline Species & 1 & 2 & 3 & 4 & 5 & 6 & 7 & 8 & 9 \\
\hline \multicolumn{10}{|l|}{ Chydoridae } \\
\hline \multicolumn{10}{|l|}{ Chydorus eurynotus Sars, 1901} \\
\hline \multicolumn{10}{|l|}{ Chydorus parvireticulatus Frey, 1987} \\
\hline \multicolumn{10}{|l|}{ Chydorus nitidulus (Sars, 1901) } \\
\hline \multicolumn{10}{|l|}{ Chydorus pubescens Sars, 1901} \\
\hline \multicolumn{10}{|l|}{ Chydorus strictomarginatus Paggi, 1972} \\
\hline \multicolumn{10}{|l|}{ Chydorus sp. } \\
\hline \multicolumn{10}{|l|}{ Dadaya macrops Sars, 1901} \\
\hline \multicolumn{10}{|l|}{ Disparalona dadayi (Birge, 1910) } \\
\hline \multicolumn{10}{|l|}{ Dunhevedia odontoplax Sars, 1901} \\
\hline \multicolumn{10}{|c|}{ Ephemeroporus cf. acanthodes Frey, 1982} \\
\hline \multicolumn{10}{|c|}{ Ephemeroporus barroisi (Richard, 1894) } \\
\hline \multicolumn{10}{|c|}{ Ephemeroporus cf. hybridus (Daday, 1905) } \\
\hline \multicolumn{10}{|c|}{ Ephemeroporus tridentatus (Bergamin, 1932) } \\
\hline \multicolumn{10}{|c|}{ Euryalona occidentalis Sars, 1901} \\
\hline \multicolumn{10}{|c|}{ Eurycercus lamellatus (O. F. Müller, 1785) } \\
\hline \multicolumn{10}{|c|}{ Graptoleberis testudinaria (Fisher, 1848) } \\
\hline \multicolumn{10}{|c|}{ Kurzia latissima (Kurz, 1974) } \\
\hline \multicolumn{10}{|l|}{ Kurzia longirostris (Daday, 1898) } \\
\hline \multicolumn{10}{|l|}{ Leydigia sp. } \\
\hline \multicolumn{10}{|l|}{ Leydigiopsis curvirostris Sars, 1901} \\
\hline \multicolumn{10}{|l|}{ Notoalona globulosa (Daday, 1898) } \\
\hline \multicolumn{10}{|l|}{ Oxyurella ciliata Bergamin, 1939} \\
\hline \multicolumn{10}{|l|}{ Oxyurella longicauda (Birge, 1910) } \\
\hline \multicolumn{10}{|l|}{ Pseudochydorus globosus (Baird, 1850) } \\
\hline \multicolumn{10}{|l|}{ Bosminidae } \\
\hline \multicolumn{10}{|l|}{ Bosmina hagmanni Stingelin, 1904} \\
\hline \multicolumn{10}{|c|}{ Bosmina longirostris (O. F. Mueller, 1785) } \\
\hline \multicolumn{10}{|c|}{ Bosmina tubicen Brehm, 1939} \\
\hline Bosminopsis deitersi Richard, 1895 & & & & & & & & & \\
\hline
\end{tabular}




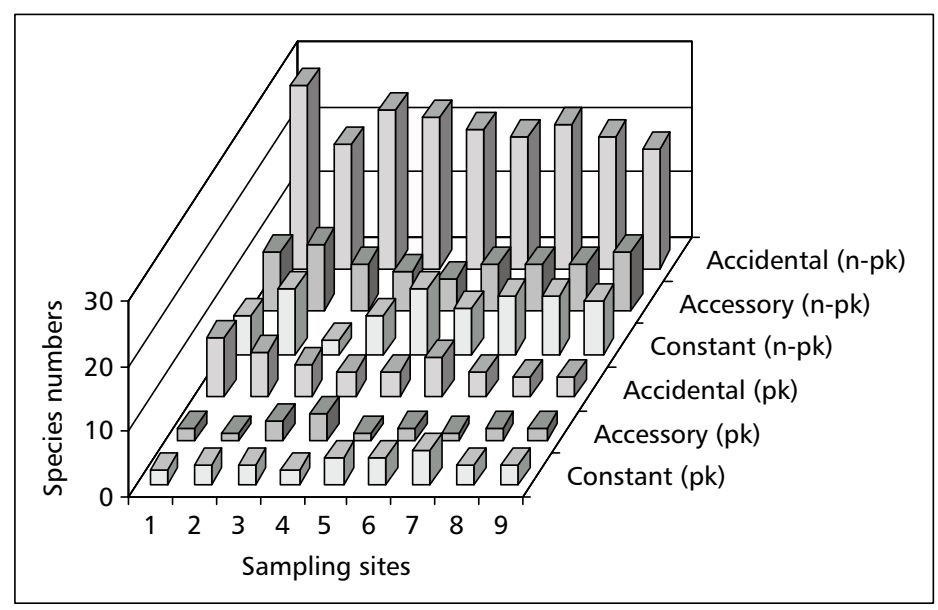

Fig. 3 - Constancy index of planktonic (pk) and non-planktonic (n-pk) cladoceran species at each sampling site.

With respect to other neotropical floodplain systems, Cladocera inventories have registered 68 species in rivers and lakes in the Central Amazon (Robertson, pers. com.), 62 species in the Orinoco River basin (Zoppi de Roa \& Vásquez, 1991), and 90 species in the floodplain of the middle Paraná River in Argentina (Paggi \& José de Paggi, 1990). Villar (1988) registered in different puruvian water bodies 76 species of which 31 were new records for Peru.

The addition of 24 new records raises the total number of Cladocera species known in the upper Paraná floodplain to 64. Leydigiopsis brevirostris, Onchobunops tuberculatus, and Scapholeberis sp., previously recorded as accidentals by Lansac-Tôha et al. (1997) in the Upper Paraná floodplain, were not found in this study. Chydorus strictomarginatus is the first record for Brazil. It was originally described as a subespecies of Chydorus eurynotus in Argentina (Paggi, 1972).

The typical littoral families contributed most to species richness. Chydoridae was represented by 39 species, 16 being new occurrences for the study area. This is probably due to the intensive sampling near macrophyte stands that harbour the littoral species. According to Frey (1986), the number of chydorid species depends on the structural diversity of the habitat, and any environmental factor that increases the distribution and diversity of macrophyte stands should consequently increase the number of chydorid species.
Lima et al. (1996), suggest that the cladoceran community associated with macrophytes changes in composition depending on macrophyte stand size, because of the dominance of pelagic and horizontally migrating species in small macrophyte beds, and dominance of littoral, non-migrating species in larger beds. It is estimated that the neotropical Chydoridae are represented by 25 genera distributed among three subfamilies (Paggi, 1995). The most representative genera in this study were Alona, Chydorus, Disparalona, and Ephemeroporus. The most constant species were Disparalona dadayi and Chydorus eurynotus, which are amply distributed on the Upper Paraná River floodplain (Lansac-Tôha et al., 1997). Another littoral species common on the floodplain is Ilyocryptus spinifer. The pelagic species B. deitersi, $B$. hagmanni, C. cornuta, and $M$. minuta are also frequent and often dominant on other floodplains (Brandorff et al., 1982; Robertson \& Hardy, 1984; Saunders III \& Lewis-Jr., 1989; Paggi \& José de Paggi, 1990; Bozelli et al., 1992; Sendacz, 1997).

Inventories of cladoceran species richness in neotropical floodplains are still few, basically because of the scarcity of studies dealing with the littoral fauna. The great number of species of Cladocera registered in the floodplain of the Amazon and the middle Paraná River is probably due to the fact that these areas have been studied for a longer time, and it is also probable that further studies in the upper Paraná floodplain will reveal more species. 
Acknowledgments - We thank Dr. Elsa Hardy and Dr. Sidney M. Thomaz, for their valuable comments. This research was supported by CAPES and PADCT/CIAMB.

\section{REFERENCES}

AGOSTINHO, A. A. \& ZALEWSKI, M., 1996, A planície alagável do alto rio Paraná: importância e preservação. EDUEM, Maringá, 100p.

BOZELLI, R. L., THOMAZ, S. M., ROLAND, F. \& ESTEVES F. A., 1992, Variações nictemerais e sazonais de alguns fatores limnológicos na represa municipal de São José do Rio Preto, São Paulo. Acta Limnol. Brasil., 6: 53-66.

BRANDORFF, G., KOSTE, W. \& SMIRNOV, N. N., 1982, The composition and structure of Rotiferan and Crustacean communities of the lower Rio Nhamundá, Amazonas, Brazil Stud. Neotrop. Fauna Environm., 17: 69-121.

CORRALES DE JACOBO, M. A. \& FRUTOS, S. M., 1985, Estudio preliminar del zooplancton de la laguna Sirena (Corrientes, Argentina). Physis, Secc. B., 43: 43-48.

DAJOZ, R., 1973, Ecologia geral. 3 ed. Vozes, Petrópolis, 471p.

ELMOOR-LOUREIRO, M. A. L., 1997, Manual de identificação de cladóceros límnicos do Brasil. Ed. Universa, Brasília, 155p.

FREY, D. G., 1986, The non-cosmopolitanism of chydorid Cladocera: implications for biogeography and evolution. In: R. H. Gore \& K. L. Heck (eds.), Crustacean Biogeography (Crustacean issues 4). Balkema, Rotterdam, pp. 237-256.

KORINEK, V., 1981, Diaphanosoma birgei n. sp (Crustacea, Cladocera), a new species from America and it's widely distribution species Diaphanosoma birgei ssp. lacustris n ssp. Can. J. Zool., 59: 1115-1121.

KOROVCHINSKY, N. M., 1992, Sididae \& Holopedidae (Crustacea: Daphniformes). SPB Academics, The Hague, $82 \mathrm{p}$. Guides to the identification of the microinvertebrate of the continental waters of the world, v.3.

KOROVCHINSKY, N. M., 1996, How many species of Cladocera are there? Hydrobiologia., 321: 191-204.

LANSAC-TÔHA, F. A., BONECKER, C. C., VELHO, L. F. M. \& LIMA, A. F., 1997, Comunidade zooplanctônica. In: A. E. A. M. Vazzoler, A. A. Agostinho \& N. S. Hahn (eds.), A planície de inundação do alto rio Paraná: aspectos físicos, químicos, biológicos e sócio-econômicos. EDUEM, Maringá, pp. 117-155.

LIMA, A. F., LANSAC-TÔHA, F. A. \& BONECKER, C. C., 1996, The microcrustacean fauna of a foodplain lake and a tributary of the high River Paraná, in Mato Grosso do Sul, Brasil. Stud. Neotrop. Fauna Environm., 31: 112-116.

MATSUMURA-TUNDISI, T., 1986, Latitudinal distribution of Calanoida copepods in freshwater aquatic systems of Brazil. Rev. Brasil. Biol., 46: 527-553.

PAGGI, J. C., 1972, Nota sistemática acerca de algunos Cladoceros del género Chydorus Leach 1843, de la República Argentina. Physis, 82: 223-236.

PAGGI, J. C., 1975, Sobre os Cladoceros Chydoridae nuevos para la fauna Argentina. Physis, 34: 139-150.

PAGGI, J. C., 1979, Aportes al conocimiento de la fauna Argentina de Cladoceros. II. Sobre Alona eximia Kiser, 1948. Neotropica, 25: 177-186.
PAGGI, J. C., 1980, Aportes al conocimiento de la fauna Argentina de Cladoceros. III Euryalona fasciculata Daday 1905 y Euryalona occidentalis Sars 1901. Rev. Asoc. Cienc. Nat. Lit., 11: 145-160.

PAGGI, J. C., 1983, Aportes al conocimiento de la fauna Argentina de Cladoceros. IV Ephemeroporus tridentatus (Bergamin 1929) (Chydoridae, Chydorinae). Rev. Asoc. Cienc. Nat. Lit., 14: 63-77.

PAGGI, J. C., 1987, Aportes al conocimiento de la fauna Argentina de Cladoceros. VI: nuevas observaciones sobre Guernella raphaelis Richard 1982 (Macrothricidae: Madrothricinae). Rev. Asoc. Cienc. Nat. Lit., 18: 29-36.

PAGGI, J. C., 1990, Ecological and biogeographical remarks on the rotifer fauna of Argentina. Rev. Hydrobiol. Trop., 23: 297-311.

PAGGI, J. C., 1993, Analisis preliminar de la distribución geográfica de los Cladoceros suramericanos. In: A. Boltovskoy \& H. L. Lopez (eds.), Conference on limnology. Instituto de Limnologia, Dr. R. A. Ringuelet, Buenos Aires, pp. 108-113.

PAGGI, J. C., 1995, Crustacea Cladocera. In: E. C. Lopretto \& G. Tell (eds.), Ecosistemas de aguas continentales. metodologías para su estudio. Ediciones Sur, La Plata, 3: 909-951p

PAGGI, J. C., Calanoids copepods from continental waters of Argentina and Uruguay. Workshop on Copepod Diversity in Neotropics, Proceedings. (in press).

PAGGI, J. C. \& JOSÉ de PAGGI, S., 1990, Zooplâncton de ambientes lóticos e lênticos do rio Paraná médio. Acta Limnol. Brasil., 3: 685-719.

ROBERTSON, B. A. \& HARDY, E. R. 1984. Zooplankton of Amazonian lakes and rivers. In: H. Sioli (ed.), The Amazon. Monographie Biological, 56: 337-352.

SAUNDERS III, J. F. \& LEWIS Jr., W. M., 1989, Zooplankton abundance in the lower Orinoco River, Venezuela. Limnol. Oceanogr., 34: 397-409.

SENDACZ, S., 1997, Zooplankton studies of floodplain lakes of the Upper Paraná River, São Paulo State, Brazil. Verh. Internat. Verein. Limnol., 26: 621-627.

SMIRNOV, N. N., 1992, The Macrothricidae of the world. SPB Academic, The Hague, 143p. Guides to the identification of the microinvertebrates of the continental waters of the world, v. 1.

SMIRNOV, N. N., 1996, Contributions to the Cladocera fauna from Papua New Guinea. Hydrobiologia, 317: 65-68.

THOMAZ, S. M., ROBERTO, M. C. \& BINI, L. M., 1997, Fatores limnológicos abióticos e clorofila $a$ : caracterização dos habitats e influências do pulso de inundação. In: A. E. A. M. Vazzoler, A. A. Agostinho \& N. S. Hahn (eds.), A planície de inundação do alto rio Paraná: aspectos físicos, químicos, biológicos e sócio-econômicos. EDUEM, Maringá, pp. 73-102.

VILLAR, R. V., 1988, Checklist of freshwater Cladocera from Peru. Amazoniana, 10: 183-197.

WARD, J. D., TOCKNER, K. \& SCHIEMER, F., 1999, Biodiversity of floodplain river ecosystems: ecotones and connectivity. Regul. Rivers Res. Mgmt., 15: 125-139.

ZOPPI de ROA, E. \& VÁSQUEZ, E., 1991, Additional cladoceran records for Mantecal and new for Venezuela. Hydrobiologia, 125: 45-62. 